\title{
Screening Indigenous Medicinal Plants of Northeast India for Their Anti-Alzheimer's Properties
}

\author{
Roohollah Sobhani ${ }^{1}$, Amarta Kumar Pal ${ }^{2}$, Atanu Bhattacharjee ${ }^{3}$, Sivaprasad Mitra ${ }^{4}$, Kripamoy Aguan $^{5 *}$
}

\section{Roohollah Sobhani', Amarta Kumar Pal' ${ }^{2}$, Atanu Bhattacharjee ${ }^{3}$, Sivaprasad Mitra ${ }^{4}$, Kripamoy Aguan ${ }^{5 *}$}

\section{'Department of Biotechnology and Bioinformatics, North Eastern Hill University, Shillong-793022, INDIA ${ }^{2}$ Department of Chemistry, North Eastern Hill University, Shillong-793022, INDIA. \\ ${ }^{3}$ Department of Biotechnology and Bioinformatics, North Eastern Hill University, Shillong-793022, INDIA. ${ }^{4}$ Department of Chemistry, North Eastern Hill University, Shillong-793022, INDIA. \\ ${ }^{5}$ Department of Biotechnology and Bioinformatics, North Eastern Hill University, Shillong-793022, INDIA. \\ Correspondence}

Kripamoy Aguan *, Department of Biotechnology and Bioinformatics, North Eastern Hill University, Shillong-793022, India.

Phone no: 919774072242

E-mail:kmaguan@gmail.com

History

- Submission Date: 05-09-2016:

- Review completed: 22-10-2016

- Accepted Date: 05-11-2016.

DOI : 10.5530/pj.2017.1.9

Article Available online

http://www.phcogj.com/v9/i1

\section{Copyright}

(C) 2016 Phcog.Net. This is an openaccess article distributed under the terms of the Creative Commons Attribution 4.0 International license.

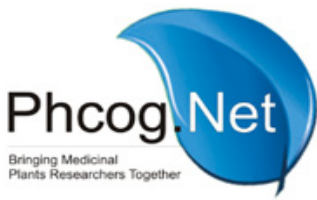

\begin{abstract}
Introduction: Alzheimer's disease (AD) is a progressive neurologic disease of the brain that affects intellectual abilities, reasoning and memory. Acetylcholine (ACh) is involved in the maintenance of cognitive process. Pathologically, ACh production is compromised in the brains of AD affected people. Presence of acetylcholinesterase (AChE) in the synaptic cleft, which hydrolyzes ACh, further decreases the ACh-levels, and thereby, additionally compromises cognition. The tribal people of North East India have been using indigenous plants as traditional medicine for brain disorders. We assayed whether the plants used in the traditional tribal knowledge for the treatment of brain disorders might contain better AChE-inhibitors. Methods: We collected 10 traditional medicinal plants from Northeast India. A total of 39 plant extracts were prepared using three solvent systems. The Acetylcholinesterase (AChE) activity was measured with Ellman method. The experiment was done in triplicate for each level of inhibitor. The activity was measured at $412 \mathrm{~nm}$ wavelength using Plate Reader. The standard student t-test was used to show significant difference in IC50 values between extracts. Results: The result are reported based on $\mathrm{Km}, \mathrm{Vmax}, \mathrm{IC}_{50}(\mu \mathrm{g} / \mu \mathrm{l})$, percentage inhibition and inhibition pattern. Two extracts had competitive inhibition, 11 extracts had mixed inhibition, 2 extracts had non-competitive inhibition, 11 extracts had uncompetitive inhibition and 4 extracts did not provide any proper pattern. The $\mathrm{IC}_{50}$ for these plant extracts were at the range of 0.51-12.4 $\mu \mathrm{g} / \mu \mathrm{l}$. Notably, Cinnamomum camphora (leaf: chloroform), Litsea glutinosa (stem; chloroform), and Litsea glutinosa (stem; methanol) showed $\mathrm{IC}_{50}$ values of 0.51 , $0.53 \& 0.81 \mu \mathrm{g} / \mu \mathrm{l}$, respectively.
\end{abstract}

Key words: AChE-inhibition, Kinetics, Medicinal plants, Alzheimer's, Ellman assay.

\section{INTRODUCTION}

Alzheimer's disease, the most common form of dementia, is a progressive neurologic disorder of the brain that leads to the irreversible loss of neurons. AD impairs cognitive and memory functions, communication, personality, behavior, and ability to function properly. The average duration of survival of $\mathrm{AD}$ patients after the onset of dementia is 5 to 9.3 years. ${ }^{1,2}$ Because of the absence of a permanent cure, AD has become a major health problem, although there are some treatments that may slow down its advances. ${ }^{3}$ It is estimated that there are 35.6 million people living with dementia worldwide and will increase to 65.7 million by 2030 , whereby much of the increase will be in developing countries. ${ }^{4}$

Neurofibrillary tangles, Amyloid plaques and loss of cholinergic neurons are three pathological findings commonly observed in the cerebral cortex of Alzheimer's disease cases..$^{5-8}$ Based on the findings that there exist a correlation between cholinergic system abnormalities and intellectual impairment, "cholinergic hypothesis" has been put forward in the functioning of memory and accepted as the foremost hypothesis in the field of $\mathrm{AD} .^{9-11}$ However, relationships between levels of acetylcholine and $\mathrm{AD}$ have been a challenge. It is now accepted that the acetylcholine dysfunction may not be the primary cause of $\mathrm{AD}$ but may be a consequence of the disease. ${ }^{9}$

The neurotransmitter acetylcholine is involved in active maintenance of novel information and enhancement of long-term potentiation, i. e. memory. ${ }^{12}$ The action of acetylcholine is terminated in the synaptic cleft by AChE which hydrolyzes ACh into acetate and choline. Amyloid plaques formation in synapse prevents acetylcholine molecules to reach its cognate receptors on the post-synaptic neuronal membrane, thereby, leading to the gradual loss of communication between neurons.

Over the years several studies have focused on "cholinergic hypothesis" to ameliorate the acetylcholine deficiency in the brain of $\mathrm{AD}$ patients. These endeavors have led the scientists to discover various classes of molecules, for the treatment of $\mathrm{AD}$, in the form of acetylcholine esterase inhibitors. ${ }^{9}$ Drugs based on cholinergic hypothesis work in prolong- 
ing the duration of acetylcholine in the synaptic cleft by inhibiting AChE activity. Some of these drugs have been synthesized and/ or derived from plants such as rivastigmine, huperzine and galanthamine etc. ${ }^{13-15}$ However, these drugs only slow down the progression of the disease and have been reported for various side effects such as gastrointestinal disturbances and bioavailability problems. ${ }^{16,17}$ These disadvantages make a room for finding newer drugs with better efficacy and lesser side effects.

In traditional practices of Ayurvedic medicine, numerous plants have been used and studied as treatment for cognitive disorders including neurodegenerative diseases such as $\mathrm{AD}$, memory enhancement, antiaging and preventing dementia. ${ }^{18}$ For example, Celastrus paniculatus Wild. (CP) has been reported to be used in Ayurvedic medicine for stimulating intellect and sharpening the memory. ${ }^{18}$ Centella asiatica (L.) Urb. (CA) is being used for anti-aging, prevention of dementia and mental exhaustion. ${ }^{18,19}$ Acorus calamus L. (AC) extract is applied for the treatment of memory loss. ${ }^{18,19}$ whiles the ripe fruit of Terminalia chebula Retz. (TC) is regarded to slow down the ageing process and to improve the cognition. ${ }^{18,19}$ Recently Mucuna pruriens (L) DC has been shown to have potential for the treatment of Parkinson's disease ${ }^{20}$ and Withania somnifera (L.) Dunal (WS) is routinely used for improvement of memory and cognition enhancement in Indian Ayurvedic medicine. ${ }^{21}$ The indigenous tribal people of North East India have been using various plants as traditional medicine for treating brain \& neurological disorders, over the millennium. Some of these plants have been shown to have AChE inhibition activity. ${ }^{22}$ In addition, Semecarpus anacardium L. f. (SA) (from North-East India), has been shown to be neuroprotective especially to the hippocampal region in stress-induced neurodegeneration. ${ }^{23}$

Given that many current AD drugs are derived from plants and the North East India belongs to one of the major biodiversity hot-spots region in the world, it would be justifiable to explore whether the plants used in the traditional tribal knowledge for the treatment of various brain ailments might contain better AChE-inhibitors. To this end, we have collected several such plants and assayed their extracts for its capacity to inhibit AChE activity. The AChE-inhibition activities of these plant parts were compared with the standard AChE-inhibitor drugs and demonstrate that some of these plants contain a good amount of AChE inhibition activity that may be further investigated for isolation of active-inhibiting component in the AD drug discovery process.

\section{MATERIAL AND METHOD}

\section{Plant material Collection \& extraction}

Under the aim of this study, different botanical books and journals were used to find the plants that are used either to treat any kind of brain disorder and/or improve the functions of brain by traditional healers in North-East India. A database of such plants was created that includes habitat, botanical and local name, purpose of use, picture of the plants and the journal or books where it was documented. Ten plants were collected from the gardens of Botanical Survey of India (BSI) which are located in the countryside of Shillong city in Meghalaya, India (with permission of Dr. B. K. Sinha, BSI Director on 03.10.2012). Proper identification and authentication of the collected plants were carried out with the help of specialist from BSI, and respective vouchers were provided. It is worth mentioning that although the plants which were collected from BSI and adjoining area of Shillong these plants may be found in other parts of India but we selected because these plants are being used by traditional healers of North East India for brain disorders.

The plants were first washed to remove dust and insects and then transferred to the clean room (out of sunlight) to dry gradually. When the plants were completely dried, different parts of the plants including, leaves, stem, root, bark, or the whole plant were pulverized and trans- ferred to autoclavable bottle with some silica gel to protect them from moisture. The bottles were labeled by the name of the plants and its part. The plant parts were extracted using three solvents including water, methanol and chloroform. The plant powder/solvent was used at the ratio of $1 \mathrm{~g} / 20 \mathrm{ml}$. The plant powder was mixed with the solvent and the bottle was sealed completely. The mixture was kept in water bath overnight at the temperature of $318 \mathrm{~K}, 318 \mathrm{~K}$ and $338 \mathrm{~K}$ for methanol, chloroform and water extract, respectively. The mixture was filtered using Whatman filter $40(110 \mathrm{~mm})$ gently. The solvents were removed using the evaporator. In order to keep the same conditions and use the same amount of extracts in experiment, all extracts were lyophilized to remove moisture and get the extract completely dry. All extracts were sealed and kept at $4^{\circ} \mathrm{C}$.

\section{Buffer and reagents preparation}

The phosphate buffer $0.1 \mathrm{M}$ was prepared at $\mathrm{pH} 7$ and $\mathrm{pH}$ 8. Acetylcholine esterase enzyme and Acetylthiocholine (ATC) substrate were purchased from Sigma. The lyophilized AChE was dissolved in $1 \%$ gelatin to obtain $1000 \mathrm{U}$ stock enzyme. The final enzyme concentration in the assay buffer was 1.4 U. Eight different final concentrations of ATC were adjusted ranging between $35.476 \mu \mathrm{M}$ and $354.770 \mu \mathrm{M}$. The stock was prepared in distilled water in buffer $\mathrm{pH}$ 8. The DTNB (5, 5'-dithiobis-(2-nitrobenzoic acid)) was obtained from SRL, India and used as a reporter reagent. The reaction between DTNB and free thiol group produces a mixed disulfide with thiols, liberating the chromospheres 2-nitro-5 thiobenzoate anion $\left(\mathrm{TNB}^{2-}\right)$ which gives an intense yellow color at $412 \mathrm{~nm}$ with a higher molar extinction coefficient. The DTNB was dissolved in $0.1 \mathrm{M}$ phosphate buffer $\mathrm{pH} 7$ in which it is more stable and used at a final concentration of $0.33 \mathrm{mM}$.

The stock solution of each plant extract, $5 \mathrm{mg} / \mathrm{ml}$, was prepared by dissolving the powder in the phosphate buffer $\mathrm{pH}$ 8. Extracts were dissolved by pipetting and vortexing gently, following a short spin to remove the particles. The supernatant was used as experimental solution. The extracts were used at final concentrations of $0.8298 \mu \mathrm{g} / \mu \mathrm{l}$ and $1.0373 \mu \mathrm{g} / \mu \mathrm{l}$. However, we would like mention that, in most of the cases, extracts dissolved in the phosphate buffer to a limited extent ranging from 30 to $100 \%$, and hence the final concentrations used $(0.8298 \mu \mathrm{g} / \mu \mathrm{l}$ and 1.0373 $\mu \mathrm{g} / \mu \mathrm{l})$ might be much lower. Tacrine, a first generation FDA approved $\mathrm{AD}$ drug and is a known non-competitive AChE inhibitor ${ }^{24,25}$ was used as a standard AChE-inhibitor control.

\section{Experimental Procedure}

The Acetylcholinesterase (AChE) activity was measured with the method developed by Ellman et al., 1961 and modified by Laura et al., 2010. The experiment was set up for the final volume of $120.5 \mu \mathrm{l}$ using 96-well plate (Greiner bio-one). The activity was measured at the wavelength of $412 \mathrm{~nm}$ using Plate Reader (Synergy H1 422, BioTek). The raw data was analyzed using Origin-Pro8 and Microsoft Excel software.

\section{Initial Velocity $\left(v_{0}\right)$}

The initial velocity $\left(\mathrm{V}_{0}\right)$ was calculated based on formation of the product at the particular time in the system. The rate or $\left(\mathrm{V}_{0}\right.$ is: $=\mathrm{V} 0=\Delta[\mathrm{P}] / \Delta \mathrm{t}$ where $[\mathrm{P}]$ is concentration of product at time $\mathrm{t}^{27}$. According to the BeerLambert Law $[\mathrm{P}]=\mathrm{A} / \varepsilon \mathrm{l}$, where $\mathrm{A}$ is absorbance, $\varepsilon$ is molar extinction coefficient and $l$ is light path length. The original molar extinction coefficient of DTNB which was reported by Ellman is $13,600 \mathrm{M}^{-1} \mathrm{~cm}^{-1}$ at $412 \mathrm{~nm}$. However, later studies have shown that the more accurate molar extinction coefficient value is $14,150 \mathrm{M}^{-1} \mathrm{~cm}^{-1}$ at $412 \mathrm{~nm}$, which has been used in this study. ${ }^{28,29}$ And 1 for $120.5 \mu \mathrm{l}$ (Greiner bio-one plate) is $0.3374 \mathrm{~cm}$. The initial velocity was calculated at the time of $5 \mathrm{~min}$. 


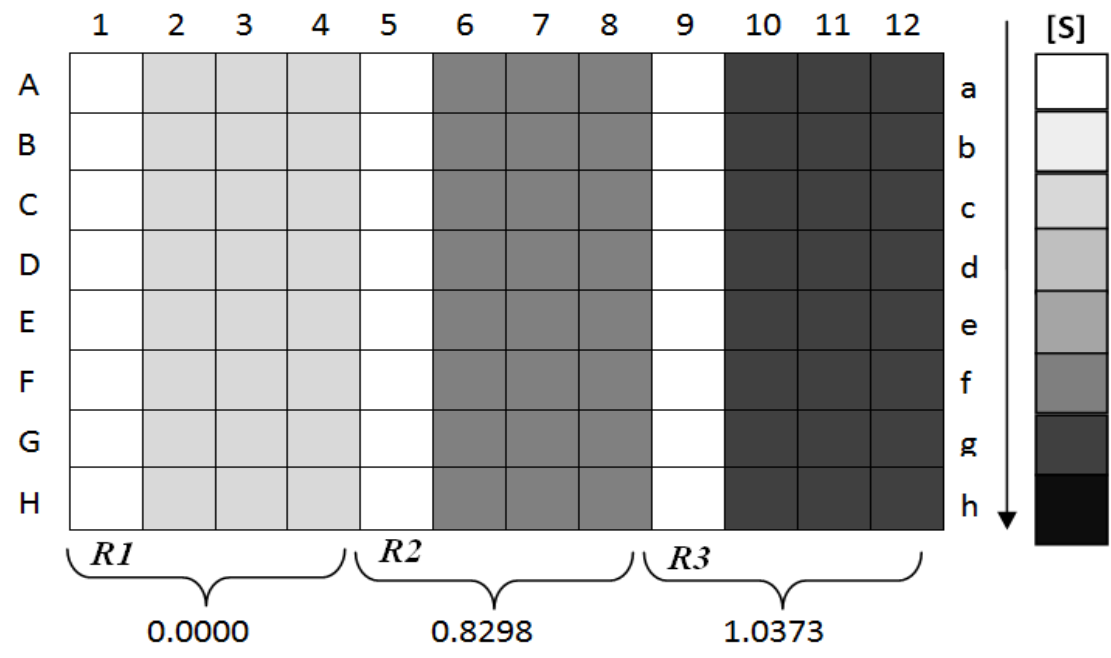

Figure 1: 96-well plate format for enzyme inhibition study. R1: Reference for A2-H4 (Zero inhibitor), R2: Reference for A6-H8 $(0.8298 \mu \mathrm{g} / \mu \mathrm{l}$ of inhibitor) and R3: Reference for A10-H12 $(1.0373 \mu \mathrm{g} / \mu \mathrm{l}$ of inhibitor).
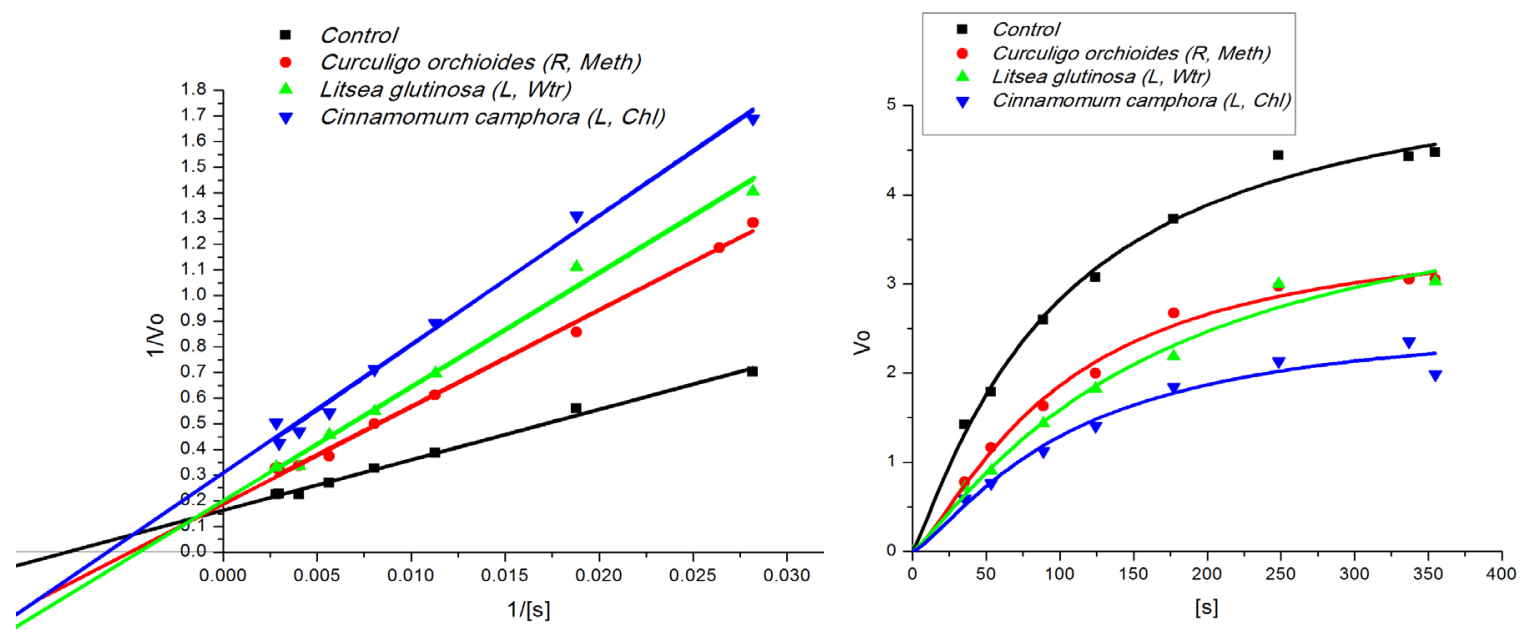

Figure 2: Lineweaver-Burk and Michaelis-Menten plot for five mixed inhibitors at the level of $1.0373 \mu \mathrm{g} / \mu \mathrm{l}$. Control: (Zero inhibition), Curculigo orchioides (Root, Methanol), Litsea glutinosa (Leaf, Water), and Cinnamomum camphora (Leaf, Chloroform).
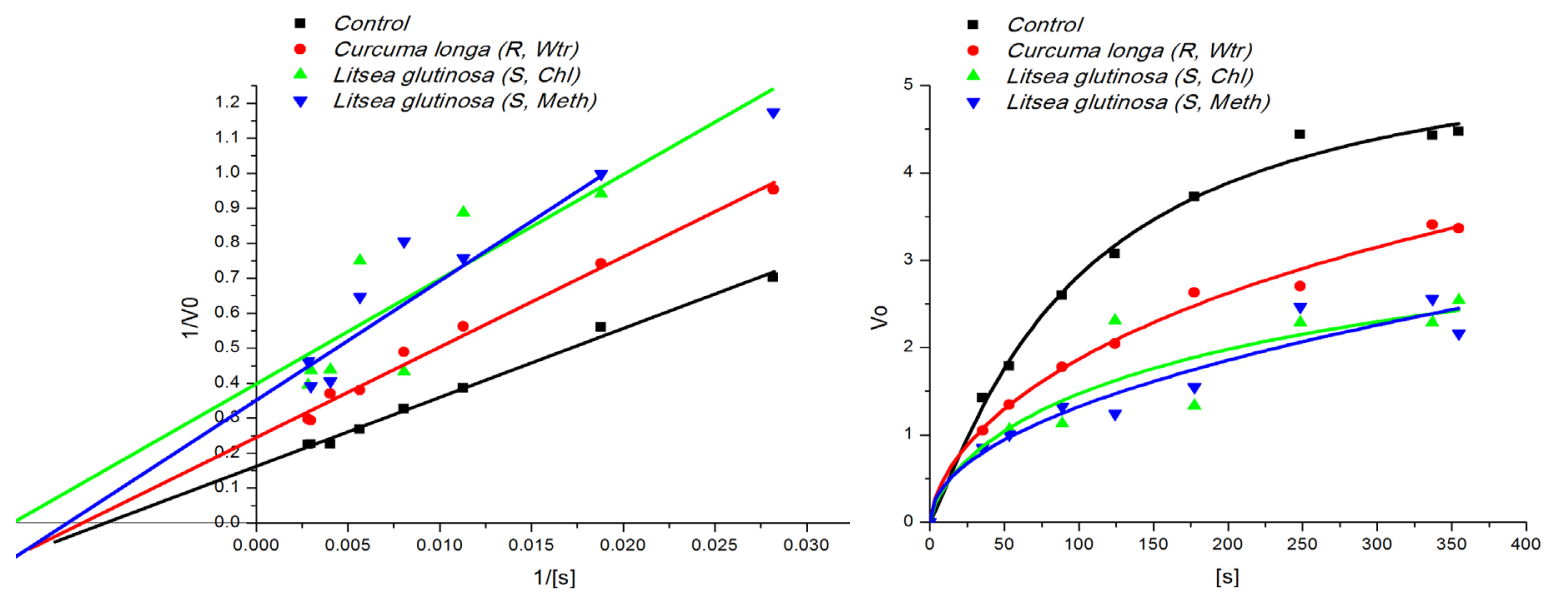

Figure 3: Lineweaver-Burk and Michaelis-Menten plot for Uncompetitive inhibitors at the level of $1.0373 \mu \mathrm{g} / \mu \mathrm{l}$. Control: (Zero Inhibition), Curcuma longa (Root, Water), Litsea glutinosa (Stem, Chloroform) and Litsea glutinosa (Stem, Methanol). 

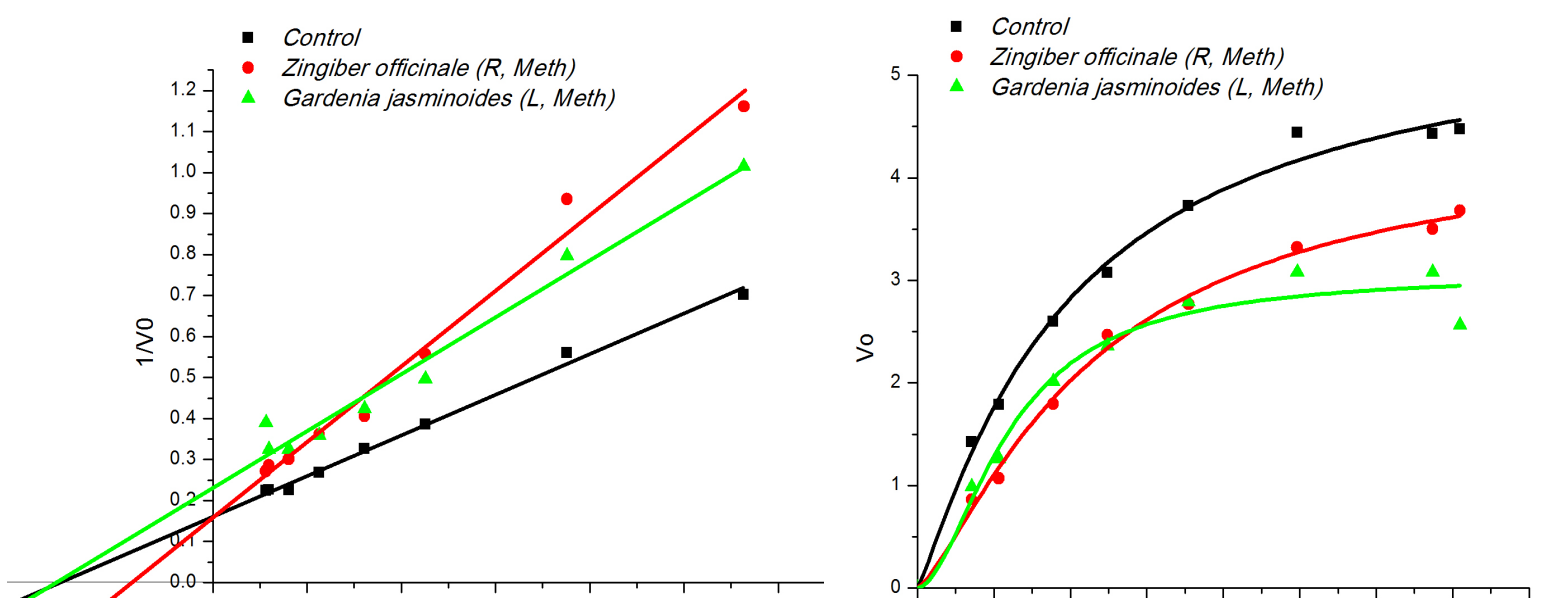

Figure 4: Lineweaver-Burk and Michaelis-Menten plot for competitive and non- competitive inhibitors at the level of $1.0373 \mu \mathrm{g} / \mu \mathrm{l}$. Control: (Zero Inhibition), Zingiber officinale (Root, Methanol competitive inhibition) and Gardenia jasminoides (Leaf, Methanol, noncompetitive inhibition).
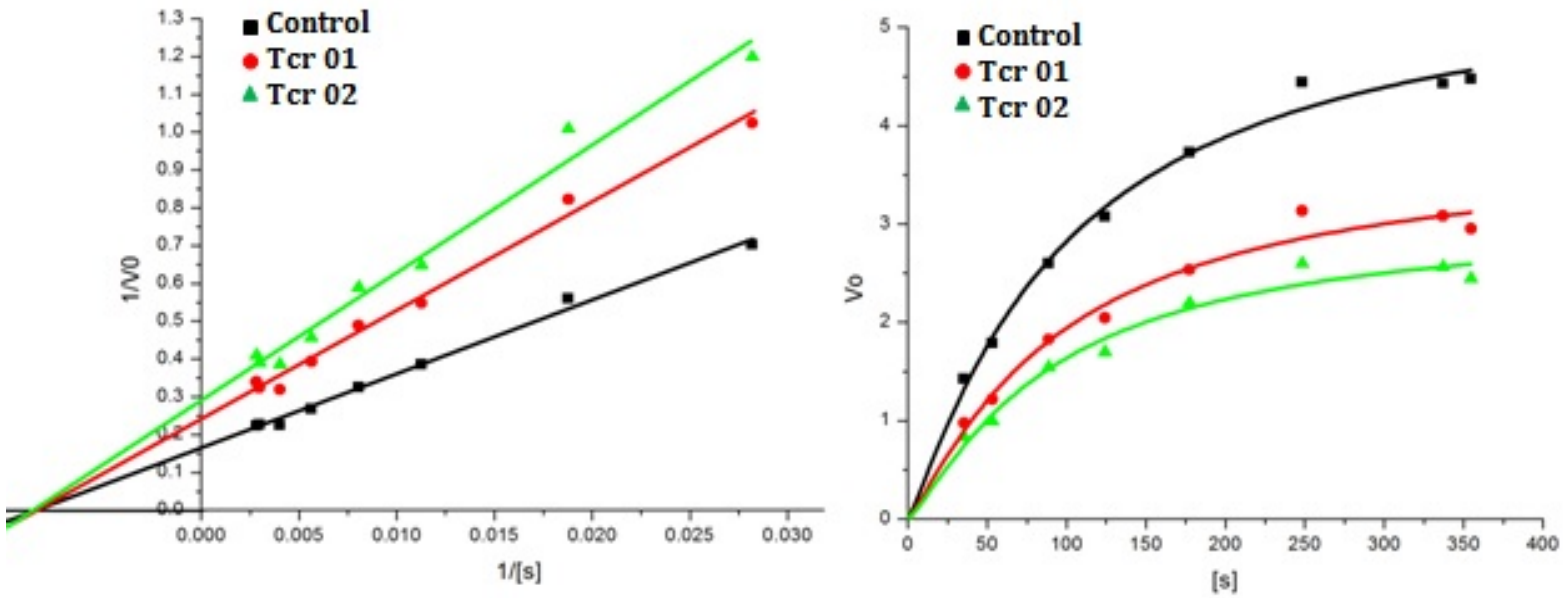

Figure 5: Lineweaver-Burk plot and Michaelis-Menten plot for Tacrine. Non-Competitive inhibition at two levels. Tacrine was used as a known AChE inhibitor that shows non-competitive inhibition to prove that the assay has been set up correctly. Control (Zero Inhibition), Tcr 01: $16.59 \mathrm{nM}$ and Tcr 02: $33.19 \mathrm{nM}$.

Table 1: The relationship between [I] / IC ${ }_{50}$ and \% for enzyme inhibition ${ }^{[27]}$

\begin{tabular}{cc}
\hline[]$/ / C_{50}$ & \% Inhibition \\
\hline 0.25 & 20 \\
0.33 & 25 \\
0.43 & 30 \\
0.50 & 33 \\
0.67 & 40 \\
1.00 & 50 \\
1.50 & 60 \\
2.33 & 70 \\
3.00 & 75 \\
4.00 & 80 \\
5.00 & 83 \\
6.00 & 86 \\
9.00 & 90 \\
19.00 & 95 \\
\hline
\end{tabular}


Table 2: The inhibition pattern and values of different parameters $\left(\% \mathrm{I}, \mathrm{IC} \mathrm{C}_{50^{\prime}}[\mathrm{I}] / \mathrm{IC} \mathrm{Co}^{\prime}, \mathrm{V}_{\max }\right.$ and $\left.\mathrm{K}_{\mathrm{m}}\right)$ for each extract

\begin{tabular}{|c|c|c|c|c|c|c|c|c|c|c|}
\hline No. & Name of Plant & Part & Solvent & $\%$ I & $\begin{array}{l}\text { IC50 } \\
\mu \mathrm{g} / \mu \mathrm{I}\end{array}$ & $\begin{array}{c}\text { [I]/ } \\
\text { IC50 }\end{array}$ & Vmax & $\mathrm{Km}$ & $\begin{array}{l}\text { Inhibition } \\
\text { Pattern }\end{array}$ & $\begin{array}{c}\text { Sample } \\
\text { No }\end{array}$ \\
\hline & $\begin{array}{l}\text { Cinnamomum } \\
\text { camphora }\end{array}$ & Leaf & Chloroform & 53.9 & 0.51 & 1.17 & 3.3 & 168 & Mixed & $06_{c}$ \\
\hline & Litsea glutinosa & Stem & Chloroform & 47.6 & 0.53 & 0.91 & $\star 2.8$ & ${ }^{\star} 97$ & Uncompetitive & 27 c \\
\hline & Litsea glutinosa & Stem & Methanol & 48.7 & 0.81 & 0.95 & 2.5 & 74 & Uncompetitive & $26_{\mathrm{m}}$ \\
\hline & Litsea glutinosa & Leaf & Water & 41.5 & 1.31 & 0.71 & 5.0 & 226 & Mixed & $28_{w}$ \\
\hline & Cassia occidentalis & Leaf & Chloroform & 28 & 1.71 & 0.39 & 4.0 & 73 & Uncompetitive & $03{ }_{c}$ \\
\hline & Curculigo orchioides & Root & Methanol & 34.5 & 1.76 & 0.52 & 5.1 & 194 & Mixed & $11_{\mathrm{m}}$ \\
\hline & Ficus religiosa & Leaf & Chloroform & 20.1 & 2.09 & 0.25 & 5.2 & 142 & Mixed & $21_{c}$ \\
\hline & $\begin{array}{l}\text { Cinnamomum } \\
\text { camphora }\end{array}$ & Leaf & Methanol & 32.8 & 2.11 & 0.49 & 4.8 & 172 & Mixed & $05_{\mathrm{m}}$ \\
\hline & Curcuma longa & Root & Water & 29 & 2.14 & 0.41 & 4.0 & 104 & Uncompetitive & $13_{\mathrm{w}}$ \\
\hline & Gardenia jasminoides & Leaf & Chloroform & 13.8 & 2.19 & 0.14 & 5.2 & 117 & N-Competitive & 24 c \\
\hline & Ficus religiosa & Leaf & Methanol & 30.7 & 2.34 & 0.44 & 4.6 & 144 & Mixed & $20_{\mathrm{m}}$ \\
\hline & Sapindus mukorossi & Leaf & Chloroform & 21.3 & 2.46 & 0.27 & 4.3 & 96 & Uncompetitive & $36_{c}$ \\
\hline & Gardenia jasminoides & Leaf & Methanol & 29.4 & 2.48 & 0.41 & 4.2 & 119 & N-Competitive & $23_{\mathrm{m}}$ \\
\hline & Litsea glutinosa & Stem & Water & 28.7 & 2.57 & 0.4 & 4.7 & 153 & Mixed & $25_{w}$ \\
\hline & Curcuma longa & Root & Methanol & 21.9 & 2.59 & 0.28 & 4.4 & 106 & Uncompetitive & $14_{\mathrm{m}}$ \\
\hline & Zingiber officinale & Root & Methanol & 23.8 & 2.97 & 0.31 & 7.5 & 286 & Competitive & $38_{\mathrm{m}}$ \\
\hline & Zingiber officinale & Root & Chloroform & 25.8 & 3.12 & 0.23 & 4.0 & 107 & Uncompetitive & $39_{c}$ \\
\hline & Curculigo orchioides & Root & Chloroform & 12.7 & 3.71 & 0.11 & $\star 6.0$ & ${ }^{*} 154$ & Mixed & $12_{c}$ \\
\hline & Cassia occidentalis & Leaf & Water & 18.5 & 4.4 & 0.23 & 4.3 & 89 & Uncompetitive & $01_{w}$ \\
\hline & Cassia occidentalis & Leaf & Methanol & 15 & 5.25 & 0.19 & $\star 5.9$ & ${ }^{\star} 164$ & Mixed & $02_{\mathrm{m}}$ \\
\hline & Gardenia jasminoides & Leaf & Water & 13.2 & 6.79 & 0.15 & 4.5 & 84 & Uncompetitive & $22_{w}$ \\
\hline & Litsea glutinosa & Leaf & Methanol & 13 & 6.92 & 0.14 & 4.7 & 95 & Uncompetitive & $29 \mathrm{~m}$ \\
\hline & Sapindus mukorossi & Leaf & Water & 12.2 & 7.44 & 0.13 & 5.6 & 132 & Mixed & $34_{w}$ \\
\hline & Sapindus mukorossi & Leaf & Methanol & 11.6 & 7.9 & 0.13 & 5.6 & 132 & Mixed & $35_{\mathrm{m}}$ \\
\hline & $\begin{array}{l}\text { Cinnamomum } \\
\text { camphora }\end{array}$ & Leaf & Water & 10.2 & 9.03 & 0.11 & 5.2 & 108 & Uncompetitive & $04_{\mathrm{w}}$ \\
\hline & Litsea glutinosa & Leaf & Chloroform & 7.71 & 12.4 & 0.08 & $\star 6.2$ & ${ }^{\star} 151$ & Competitive & $30_{c}$ \\
\hline & Curculigo orchioides & Root & Water & NA & NA & NA & NA & NA & NA & $10_{w}$ \\
\hline & Curcuma longa & Root & Chloroform & NA & NA & NA & NA & NA & NA & 15 c \\
\hline & Ficus religiosa & Leaf & Water & NA & NA & NA & NA & NA & NA & $19_{\mathrm{w}}$ \\
\hline & Zingiber officinale & Root & Water & NA & NA & NA & NA & NA & NA & $37_{\mathrm{w}}$ \\
\hline & Tacrine & & & & & 0.74 & 3.45 & 117 & $\mathrm{~N}$-Competitive & \\
\hline
\end{tabular}

$\mathrm{V}_{\max }$ and $\mathrm{K}_{\mathrm{m}}$ of control assay were 6.1 and 120 respectively (8 substrate concentrations). $\mathrm{V}_{\max }$ and $\mathrm{K}_{\mathrm{m}}$ of control assay were 6.5 and 139 for those which have been marked with star $\left(^{*}\right)$ (7 substrate concentrations). $\mathrm{K}_{\mathrm{i}}$ has not been mentioned here as it was not useful to compare the inhibition activity between two different extracts. Tacrine has been reported based on nanomolar. Water: $\left({ }_{\mathrm{w}}\right)$, Methanol: $\left({ }_{\mathrm{m}}\right)$ and Chloroform: $\left({ }_{\mathrm{c}}\right)$. 
Table 3: Student t-test to compare $\mathrm{IC}_{50}$ values for those which have less than $\mathbf{3} \boldsymbol{\mu g} / \boldsymbol{\mu l}$

\begin{tabular}{|c|c|c|c|c|c|c|c|c|c|c|c|c|c|c|c|}
\hline & $05_{\mathrm{m}}$ & $06_{c}$ & $11_{\mathrm{m}}$ & $13_{w}$ & $14_{\mathrm{m}}$ & $20_{m}$ & $21_{c}$ & $23_{m}$ & $24_{c}$ & $25_{w}$ & $26_{m}$ & $27_{c}$ & $28_{w}$ & $36_{c}$ & $38_{m}$ \\
\hline $03_{c}$ & 0 & $1^{*}$ & 0 & 0 & 0 & 0 & 0 & 0 & 0 & 0 & 0 & $1^{*}$ & 0 & 0 & $1^{*}$ \\
\hline $05_{\mathrm{m}}$ & & $1^{* *}$ & 0 & 0 & 0 & 0 & 0 & 0 & 0 & 0 & $1^{* *}$ & $1^{* *}$ & 0 & 0 & 0 \\
\hline $06_{c}$ & & & $1^{* *}$ & $1^{* *}$ & $1^{* *}$ & $1^{* *}$ & $1^{* *}$ & $1^{* *}$ & $1^{* *}$ & $1^{* *}$ & 0 & 0 & 0 & $1^{* *}$ & $1^{* *}$ \\
\hline $11_{\mathrm{m}}$ & & & & 0 & 0 & 0 & 0 & 0 & 0 & 0 & $1^{*}$ & $1^{* *}$ & 0 & 0 & $1^{*}$ \\
\hline $13_{w}$ & & & & & 0 & 0 & 0 & 0 & 0 & 0 & $1^{* *}$ & $1^{* *}$ & 0 & 0 & 0 \\
\hline $14_{\mathrm{m}}$ & & & & & & 0 & 0 & 0 & 0 & 0 & $1^{* *}$ & $1^{* *}$ & $1^{*}$ & 0 & 0 \\
\hline $20_{\mathrm{m}}$ & & & & & & & 0 & 0 & 0 & 0 & $1^{* *}$ & $1^{* *}$ & $1^{*}$ & 0 & 0 \\
\hline $21_{c}$ & & & & & & & & 0 & 0 & 0 & $1^{* *}$ & $1^{* *}$ & 0 & 0 & 0 \\
\hline $23_{\mathrm{m}}$ & & & & & & & & & 0 & 0 & $1^{* *}$ & $1^{* *}$ & $1^{*}$ & 0 & 0 \\
\hline $24_{c}$ & & & & & & & & & & 0 & $1^{* *}$ & $1^{* *}$ & 0 & 0 & 0 \\
\hline $25_{w}$ & & & & & & & & & & & $1^{* *}$ & $1^{* *}$ & $1^{*}$ & 0 & 0 \\
\hline $26_{m}$ & & & & & & & & & & & & 0 & 0 & $1^{* *}$ & $1^{* *}$ \\
\hline 27 c & & & & & & & & & & & & & 0 & $1^{* *}$ & $1^{* *}$ \\
\hline $28_{w}$ & & & & & & & & & & & & & & $1^{*}$ & $1^{* *}$ \\
\hline $36_{c}$ & & & & & & & & & & & & & & & 0 \\
\hline
\end{tabular}

Not significant: (0), significant for $\alpha=0.05:\left(1^{*}\right)$ and for $\alpha=0.01$ : $\left(1^{* *}\right)$. The table shows the difference not only between two different plants but also between two different solvent for same plant.

\section{Plots}

The Michaelis-Menten plot was graphed using $\mathrm{V}_{0}$ versus [S]. The Line weaver-Burk plot was used to calculate $\mathrm{V}_{\max }$ (maximum velocity) and $\mathrm{K}_{\mathrm{m}}$ (Michaelis constant). The initial velocity of AChE was calculated for each substrate concentration individually. $\mathrm{V}_{\max }$ (No inhibitor), $\mathrm{V}_{\max }^{\text {app }}$ (with Inhibitor), $\mathrm{K}_{\mathrm{m}}$ (No inhibitor) and $\mathrm{K}_{\mathrm{m}}^{\text {app }}$ (with Inhibitor) were calculated by plotting the graph of $1 / \mathrm{V}_{0}$ versus $1 /[\mathrm{s}]$. The proper inhibition pattern for each level of inhibitor was plotted. $\mathrm{K}_{\mathrm{i}}$ (Inhibition constant), $\% \mathrm{I}$ (\%Inhibition) and $\mathrm{IC}_{50}$ was calculated accordingly.

To calculate the \%I the following equation was used:

$$
\% \text { inhibition }=100 *\left[1-\left(\mathrm{V}_{\mathrm{i}} / \mathrm{V}_{0}\right)\right]
$$

Where $\left(\mathrm{V}_{\mathrm{i}} / \mathrm{V}_{0}\right)$ is the fractional activity therefore $\left[1-\left(\mathrm{V}_{\mathrm{i}} / \mathrm{V}_{0}\right)\right]$ is the fraction of enzyme occupied by inhibitor. $V_{i}$ and $V_{0}$ are reaction velocity at the presence and absence of inhibitor. ${ }^{27}$

The following equations were used to calculate $\mathrm{IC}_{50}$ and relationship between [I]/ $\mathrm{IC}_{50}$ and \%I of enzyme activity: ${ }^{27}$

$$
\begin{aligned}
& \mathrm{V}_{\mathrm{i}} / \mathrm{V}_{0}=1 / 1+\left([\mathrm{I}] / \mathrm{IC}_{50}\right)^{\mathrm{h}} \\
& \% \mathrm{I}=100 / 1+\left(\mathrm{IC}_{50} /[\mathrm{I}]\right)^{\mathrm{h}}
\end{aligned}
$$

Where $[\mathrm{I}]$ is the concentration of inhibitor (extract) and $h$ is Hill coefficient which is related to number of active site of the enzyme and interaction between inhibitor and enzyme.

After rearranging the equation E2 the following equation can be used to calculate $\mathrm{IC}_{50}$ :

$$
[\mathrm{I}]=\mathrm{IC}_{50}\left[\left(\mathrm{~V}_{0} / \mathrm{V}_{\mathrm{i}}\right)-1\right]^{1 / \mathrm{h}}
$$

Where, $\left(\mathrm{V}_{0} / \mathrm{V}_{\mathrm{i}}\right)$ is reciprocal of fraction activity.

Looking at the equation $\mathrm{E} 4$ we see that at the point of $50 \%$ inhibition, the fractional activity will be 0.50 and its reciprocal will be equal to 2.00 . It means when $50 \%$ inhibition is achieved then $[\mathrm{I}] / \mathrm{IC}_{50}$ is equal to 1.00 . And if the $[\mathrm{I}] / \mathrm{IC}_{50}$ is calculated for different \%I (i.e. 25\%, 30\%, 50\%, 75\% and etc.), given $h$ is equal to 1 , the standard values as mentioned in Table 1 can be obtained. ${ }^{27}$
By rearrangement of the standard Langmuir isotherm equation the relationship between [I] / $\mathrm{IC}_{50}$ and \% I for enzyme inhibition was calculated: ${ }^{27}$

$$
[\mathrm{I}] / \mathrm{IC}_{50}=\% \mathrm{I} /(100-\% \mathrm{I})
$$

The standard values mentioned in Table 1 were used to evaluate whether our calculation is correct ${ }^{27}$ (Table 1).

In order to show that how large a difference in $I C_{50}$ between two extracts can be considered significant, the standard student $t$-test was used: $:^{27,30}$

$$
\mathrm{t} \text {-value }=\left|\mathrm{IC}_{50}{ }^{\mathrm{a}}-\mathrm{IC}_{50}{ }^{\mathrm{b}}\right| / \sqrt{ } \mathrm{S}_{\mathrm{a}}{ }^{2} \mathrm{n}_{\mathrm{a}}+\mathrm{S}_{\mathrm{b}}{ }_{\mathrm{b}} / \mathrm{n}_{\mathrm{b}}
$$

Where, $\mathrm{a}$ and $\mathrm{b}$ identify two inhibitors (extracts), and $\mathrm{S}_{\mathrm{a}}$ and $\mathrm{S}_{\mathrm{b}}$ are standard errors of each $\mathrm{IC}_{50}$ value, $\mathrm{n}_{\mathrm{a}}$ and $\mathrm{n}_{\mathrm{b}}$ are number of data points for two inhibitors (extracts) respectively.

As our experiment was set up in triplicate, therefore, the degrees of freedom for testing the significance of $t$-value was calculated using following equation: $:^{27,30}$

$$
\mathrm{df}=\left\{\left[\left(\mathrm{n}_{\mathrm{a}}^{\star} 3\right)-1\right]+\left[\left(\mathrm{n}_{\mathrm{b}}{ }^{\star} 3\right)-1\right]\right\}
$$

Where $\mathrm{n}_{\mathrm{a}}$ and $\mathrm{n}_{\mathrm{b}}$ are number of data points for two inhibitors (extracts) respectively.

The experiment was set up for three levels of inhibitors (extract) 0.0000, 0.8298 and $1.0373 \mu \mathrm{g} / \mu \mathrm{l}$. The activity without any inhibitor was negative control and Tacrine as known inhibitor was used as positive control. The experiment was done in triplicate for each level of inhibitor plus one column (eight wells) as reference $(\boldsymbol{R})$ without enzyme. Because of nonenzymatic reaction between DTNB and substrate or inhibitors some absorbance will be detected as background which must be subtracted from the activity columns. Therefore, the reference column must include all reagents present in activity columns except enzyme (Figure 1).

\section{RESULTS}

A total of 30 extracts of 9 plants were screened for AChE inhibition activity. The inhibition pattern was found for each extract by plotting $1 / \mathrm{V}_{0}$ versus $1 /[\mathrm{S}]$ (Lineweaver-Burk plot). The following were the distribution of inhibition patterns: Two extracts had competitive inhibition, 11 extracts had mixed inhibition, 2 extracts had non-competitive inhibition, 
11 extracts had uncompetitive inhibition and 4 extracts did not provide any proper pattern (Table 2). AChE has Michaelis constant of $90 \mu \mathrm{M} .^{31}$ In this study, the maximum velocity and Michaelis constant for control assay (zero-inhibitor) were obtained as 6.1 and $120 \mu \mathrm{M}$, respectively, using eight different substrate concentrations. However, only for four assays we used seven different substrate concentrations and their $\mathrm{V}_{\max }$ and $\mathrm{K}_{\mathrm{m}}$ were of 6.5 and $139 \mu \mathrm{M}$. Based on obtained initial velocities and substrate concentrations, six different parameters including \% $\mathrm{I}_{1} \mathrm{IC}_{50},[\mathrm{I}] /$ $\mathrm{IC}_{50}, \mathrm{Ki}, \mathrm{V}_{\max }$ and $\mathrm{K}_{\mathrm{m}}$ were calculated for each extract. $\mathrm{V}_{\max }$ and $\mathrm{K}_{\mathrm{m}}$ were used to prove that the inhibition pattern has obtained correctly. Three parameters including $\% \mathrm{I}, \mathrm{IC}_{50}$ and $[\mathrm{I}] / \mathrm{IC}_{50}$ were used to compare the inhibition activity of extracts.

We calculated a very important parameter $\left([\mathrm{I}] / \mathrm{IC}_{50}\right)$ and its relationship with \%I. We compared our results for $\left([\mathrm{I}] / \mathrm{IC}_{50}\right)$ and $\% \mathrm{I}$ with the standard values mentioned in Table 2 . We found that relationship values between $\left([\mathrm{I}] / \mathrm{IC}_{50}\right)$ and \% $\mathrm{I}$ of our data was in good agreement with the standard values. This indicates that our calculation for $\% \mathrm{I}$ and $\mathrm{IC}_{50}$ are correct. In order to show that how much difference between two values of $\mathrm{IC}_{50}$ is considered significant, the Student t-test was done for those which have shown more than $20 \%$ inhibition. The t values were calculated at $\alpha=0.05$ and $\alpha=0.01$ (2 tail) (Table 3)..$^{27,30}$

The Lineweaver-Burk and Michaelis-Menten plots have been shown in Figures 2, 3 and 4 for mixed inhibition, uncompetitive inhibition, competitive inhibition and non-competitive inhibition. The plots for Tacrine, as a known AChE inhibitor, have been shown in Figure 5 to demonstrate that the enzyme assay was working correctly.

\section{DISCUSSION}

Pathologically, the formation of Amyloid plaques in synapse impedes the access of acetylcholine molecules to reach their cognate receptors on the post-synaptic membrane to deliver their message. In fact, gradual build up of Amyloid plaques in the synapse slows down the action of acetylcholine and leading to the loss of communication between neurons. Inhibiting AChE would mean that more acetylcholine molecules would be available in the synaptic cleft to deliver the message before they are being catalyzed by AChE.

Therefore, to increase the acetylcholine levels in the brains of $\mathrm{AD}$ patients, search for AChE-inhibitors has led to the discovery of plant derived drugs such as Rivastigmine, huperzine and Galanthamine. Rivastigmine and Galanthamine have been isolated from two different plants, Calabar bean (Physostigma venenosum) and bulbs of snowdrop (Galanthus woronowii Los.), respectively, while huperzine A (HupA) has been isolated from moss (Huperzia serrata (Thunb. Ex Murray) Trev.). HupA is selectively potent and reversible inhibitor with a better therapeutic index than physostigmine and tacrine. ${ }^{32}$ In fact, HupA is clinically prescribed in China for symptomatic treatment of AD. In spite of their excellent AChE-inhibition capacity, the above drugs have serious side effects such as Nausea, vomiting, diarrhea, weight loss, loss of appetite and muscle weakness. ${ }^{3,18}$ Many other plant compounds have shown remarkable AChE inhibitory capacity, for example, withanolides from Withania somnifera Dunal. (ashwaganda or Indian ginseng), curcuminoids from Curcuma longa L., tanshinones from Salvia miltiorrhiza Bunge and quercetin from Quercus sp. (oak) and their full potentials has yet to be investigated. ${ }^{33-37}$ Therefore, it seems that plants have a vast kingdom of natural sources of several compounds for combating neurodegenerative diseases.

In this study, 30 plant extracts were assayed at two levels of plant extract concentrations, $0.829 \mu \mathrm{g} / \mu \mathrm{l}$ and $1.037 \mu \mathrm{g} / \mu \mathrm{l}$. Two extracts have shown competitive inhibition in which inhibitor only binds to free enzyme and $\mathrm{V}_{\max }$ remains same but $\mathrm{K}_{\mathrm{m}}$ increases. Eleven extracts have shown mixed inhibition in which inhibitor can bind to either free enzyme or enzyme- substrate both and herein $\mathrm{V}_{\max }$ decreases while $\mathrm{K}_{\mathrm{m}}$ increases. Two extracts have shown non-competitive inhibition. Non-competitive inhibitors bind to enzyme and enzyme-substrate both with equal affinity and $\mathrm{K}_{\mathrm{m}}$ remains same but $\mathrm{V}_{\max }$ decreases. Eleven extracts have shown uncompetitive inhibition in which inhibitor only binds to enzyme-substrate complex. In uncompetitive pattern $\mathrm{V}_{\max }$ and $\mathrm{K}_{\mathrm{m}}$ both decrease. And finally, 4 extracts have not given any proper pattern (Table 2 ).

Working with natural plant inhibitors is very cumbersome as different molecules are present in plant extract. Hence, using different concentration of the same crude extract might show variant inhibition patterns. Therefore, it is often difficult to find an inhibition pattern that may be appropriate for a certain plant extract and unlike pure compounds it is impossible to use $\mathrm{K}_{\mathrm{i}}$ to compare the inhibition activity of the plant extracts. In fact, even in pure compounds if they do not have similar inhibition pattern, $\mathrm{K}_{\mathrm{i}}$ cannot be a proper parameter to compare. Based on the type of reaction between inhibitor and enzyme, there are different types of inhibition patterns and different types of calculations for $\mathrm{K}_{\mathrm{i}}$. Having said that, it seems it won't be correct if we use $\mathrm{K}_{\mathrm{i}}$ as a comparison parameter to select the inhibitor. That is why we have not mentioned $\mathrm{K}$ values in the Table 2, although the values have been calculated for all extracts.

Therefore, it is necessary to have a particular comparison parameter which should have two important aspects. First, it should be independent parameter that is it should not be influenced by the type of reaction between inhibitor and enzyme. Secondly, it should be applicable for both pure and crude samples. Practically in inhibition kinetics, it seems percentage inhibition (\% I) and $\mathrm{IC}_{50} / \mathrm{EC}_{50}$ are the best parameters which can be used to select inhibitors. The $\% \mathrm{I}$ and $\mathrm{IC}_{50} / \mathrm{EC}_{50}$ are using velocities directly (as first step values) and they are independent from the type of reaction between inhibitor and enzyme while $\mathrm{K}_{\mathrm{m}}$ and $\mathrm{V}_{\max }$ (as second step values) are necessary to calculate $\mathrm{K}_{\mathrm{i}}$ and they are not independent.

When we work with crude samples, we have to consider the following things. Firstly, we assayed the crude plant extract so we do not have any idea of what would be the real percentage of the active compound (that inhibits AChE) in the crude extract. Generally, percentage of any active compound in plant extract is much less than $1 \%$. Secondly, because the crude contains several other compounds, these compounds will effectively inhibit and/or dampen the access of the active compound for AChE site and thus may display lesser inhibition capacity. Third, the active compound might be in complex with other compounds which will prevent the reaction between active compound and $\mathrm{AChE}$ and reduce the inhibition activity. Fourth, being in complex condition might change the solubility of active compound leading to reduction of active compound concentration in the stock solution. Fifth, as we are using crude plant extracts there might be some compounds which can increase the AChE activity, thereby reducing inhibitory potential of the active-inhibiting compound. Therefore, keeping all these in mind, it is not fair to compare the inhibition-activity of a pure compound that with crude extract.

In this study the best $\mathrm{IC}_{50}$ with $0.51 \mu \mathrm{g} / \mu \mathrm{l}$ belongs to Cinnamomum camphora (leaf: chloroform) following by Litsea glutinosa $0.53 \mu \mathrm{g} / \mu \mathrm{l}$ (stem; chloroform), Litsea glutinosa $0.81 \mu \mathrm{g} / \mu \mathrm{l}$ (stem; methanol) and Litsea glutinosa $1.31 \mu \mathrm{g} / \mu \mathrm{l}$ (leaf; Water) (Table 2). We found 20 plant extracts having more than $20 \%$ inhibition and specifically the above mentioned plants displayed \% inhibition range varying from $40-54 \%$. Other studies on different plants have reported more than $70 \%$ inhibition using plant extract concentration of $1 \mathrm{mg} / \mathrm{ml} .{ }^{16,38}$ But first, none of them clarified for how they have done the analysis and calculations for \% I and $\mathrm{IC}_{50}$ using the velocities and inhibitor concentrations and what was the relationship between all these parameters. Secondly, \%I is not a good parameter to compare two different plant extracts because it is almost impossible to use the same amount of different plant extracts due to 
their solubility in phosphate buffer. That is why we should use \%I only to calculate the $\mathrm{IC}_{50}$ for each extract independently and then use $\mathrm{IC}_{50}$ for comparison. As we have found during our analysis, although we use the same data to calculate all these different parameters (\% $, \mathrm{IC}_{50}, \mathrm{~V}_{\max }, \mathrm{K}_{\mathrm{m}}$ and $\mathrm{K}_{\mathrm{i}}$ ), if we do not care about the relationship between parameters the calculation will be wrong and there is a high chance of getting a higher percentage of inhibition. We have searched through literatures but did not find such a study which had examined the plants we studied and given all the kinetic parameters that we calculated. Hence, we could not compare our results with others.

We have compared the $\mathrm{IC}_{50}$ values for those which have less than $3 \mu \mathrm{g} / \mu \mathrm{l}$ of $\mathrm{IC}_{50}$ by Student $\mathrm{t}$-test in Table 3 in order to see how much difference between two $\mathrm{IC}_{50}$ is considered significant. ${ }^{27,30}$ For each $\mathrm{IC}_{50}$ there is a particular range to be significant from others, up and down. Calculation of the $t$ value and knowing the difference between two extracts can be very useful if we use the extracts for further separation and purification and/ or experiments using cell line or mouse model. It can be helpful when the toxicity and availability of the plant extract is considered.

In nutshell, our results demonstrate that selected plants from North East India collected and assayed under the current study contain appreciable amount of AChE-inhibitors. It is therefore imperative that more such plants of North East India are screened for potential AChE-inhibitors, which could pave the way for the development of new classes of chemical compounds. Currently our work is under way for further separation and assaying of the extract fractions which might provide much better AChE-inhibition profile. The comparative study of the isolated fraction against known AChE-inhibiting drugs could provide valuable insight for development of newer lead compounds.

\section{CONCLUSION}

Plants used by the traditional Tribal healers of Northeast India for the treatment of brain disorders contain appreciable amount of AChEinhibitors. These inhibitors might have better safety profile since they have been used by the tribes for millennium. Importantly, these inhibitors may belong to new classes of compound paving the way to develop lead compound for better AChE-inhibitors. Further screening of other plants used in tribal medical interventions in the Northeast India may provide better AChE-inhibitors.

\section{ABBREVIATION}

AD: Alzheimer's Disease; ACh: Acetylcholine; AChE: $\mathrm{K}_{\mathrm{m}}^{\mathrm{app}} \mathrm{V}_{\max }^{\mathrm{app}}$ Acetylcholinesterase; : Apparent Michaelis Constant; : Apparent maximum velocity; $\mathrm{IC}_{50}$ : inhibitory concentration; BSI: botanical survey of India; ATC: Acetylthiocholine; DTNB: 5, 5'-dithiobis-(2-nitrobenzoic acid; TNB $^{2-}$ : 2-nitro-5 thiobenzoate anion; $\mathrm{V}_{0}$ : initial velocity; $[\mathrm{P}]$ : Product concentration; [S]: Substrate concentration; Ki: Inhibitory constant; \%I: percentage of inhibition; [I]: Inhibitor concentration; R: Reference (Blank); HupA: Huperzine A.

\section{REFERENCES}

1. Wolfson C, Wolfson DB, Asgharian M, Emile M'lan C, Ostbye T, et al., A reevaluation of the duration of survival after the onset of dementia. $\mathrm{N}$ Engl J Med. 2001;344(15):1111-6. http://dx.doi.org/10.1056/NEJM200104123441501; PMid:11297701

2. Walsh JS, Welch G, Larson EB, Welch HG. Survival of outpatients with Alzheimertype dementia. Ann Intern Med. 1990;113(6):429-34. http://dx.doi.org/10.7326/ 0003-4819-113-6-429; PMid:2386336.

3. Chu J, Li JG, Joshi YB, Giannopoulos PF, Hoffman NE, Madesh M, et al., Gamma secretase-activating protein is a substrate for caspase-3: implications for alzheimer's disease. Biological psychiatry. 2015;77(8):720-8. http://dx.doi. org/10.1016/j.biopsych.2014.06.003 ; PMid:25052851 PMCid:PMC4268092.

4. Duthey B. Alzheimer's Disease and other dementias. World Health Organization. http://www.who.int/medicines/areas/priority_medicines/BP6_11Alzheimer.pdf. 20 February 2013.
5. Tomlinson BE, Blessed G, Roth M. Observation on the brains of demented old people. J Neurol Sci. 1970;11(3):205-42. http://dx.doi.org/10.1016/0022510x(70)90063-8.

6. Ball MJ. Neuronal loss, neurofibrillary tangles and granulovacuolar degeneration in the hippocampus with ageing and dementia. ActaNeuropathol (Berl). 1977;37(2):111-8. http://dx.doi.org/10.1007/BF00692056.

7. Terry RD, Peck A, DeTeresa R, Schechter R, Horoupian DS. Some morphometric aspects of the brain in senile dementia of the Alzheimer type. Ann Neurol. 1981;10(2):184-92. http://dx.doi.org/10.1002/ana.410100209 ; PMid:7283403.

8. Mountjoy CQ, Roth M, Evans NJR, Evans HM. Cortical neuronal counts in normal elderly controls and demented patients. Neurobiol Aging. 1983;4(1):1-11. http:// dx.doi.org/10.1016/0197-4580(83)90048-9.

9. Tabet N. Acetylcholinesterase inhibitors for Alzheimer's disease: anti-inflammatories in acetylcholine clothing. Age and Ageing. 2006;35(4):336-8. http://dx.doi. org/10.1093/ageing/afl027; PMid:16788077.

10. Perry EK, Tomilinson BE, Blessed G, Bergmann K, Gibson PH, Perry RH Correlation of cholinergic abnormalities with senile plaques and mental test scores in senile dementia. Br Med J. 1978;2(6150):1457-9. http://dx.doi. org/10.1136/bmj.2.6150.1457; PMid:719462 PMCid:PMC1608703.

11. Bartus RT, Dean RL III, Beer B, Lippa AS. The cholinergic hypothesis of geriatric memory dysfunction. Science. 1982:217(4558):408-14. http://dx.doi. org/10.1126/science.7046051; PMid:7046051.

12. Hasselmo ME. The Role of Acetylcholine in Learning and Memory. CurropinNeurobiol. 2006;16(6):710-5. http://dx.doi.org/10.1016/j.conb.2006.09.002.

13. Dall' Acqua S. Plant-derived acetylcholinesterase inhibitory alkaloids for the treatment of Alzheimer's disease. Botanics: Targets and Therapy. 2013;3:19-28. http://dx.doi.org/10.2147/BTAT.S17297.

14. Houghton PJ, Howes MJ. Natural products and derivatives affecting neurotransmission relevant to Alzheimer's and Parkinson's disease. Neurosignals. 2005;14(1-2):6-22. http://dx.doi.org/10.1159/000085382 ; PMid:15956811.

15. Houghton PJ, Ren Y, Howes MJ. Acetylcholinesterase inhibitors from plants and fungi. Nat Prod Rep. 2006;23(2):181-199. http://dx.doi.org/10.1039/b508966m; PMid:16572227.

16. Mukherjee PK, Kumar V, Mal M, Houghton PJ. Acetylcholinesterase inhibitors from plants. Phytomedicine. 2007;14:289-300. http://dx.doi.org/10.1016/j.phymed.2007.02.002; PMid:17346955

17. Schulz V. Ginkgo extract or cholinesterase inhibitors in patients with dementia: what clinical trial and guidelines fail to consider. Phytomedicine. 2003;10:74-9 http://dx.doi.org/10.1078/1433-187X-00302 ; PMid:12807348

18. Howes MJ, Houghton PJ. Plants used in Chinese and Indian traditional medicine for improvement of memory and cognitive function. Pharmacol Biochem Behav. 2003;75(3):513-27. http://dx.doi.org/10.1016/S0091-3057(03) 00128-X.

19. Manyam BV. Dementia in Ayurveda. J Altern Complement Med. 1999:5(1):81-88 http://dx.doi.org/10.1089/acm.1999.5.81; PMid:10100034.

20. Huisden CM. Modern-day naturopathic medicine and traditional Ayurveda in a combined attack against Parkinson's disease. Academic Journal of Suriname. 2010;1:53-58.

21. Vinutha $B$, et al. Screening of selected Indian medicinal plants for acetylcholinesterase inhibitory activity. Journal of Ethnopharmacology. 2006;1109(2):359-63.

22. Phukan P, Bawari M, Sengupta M. Promising Neuroprotective Plants from North-East India. Int J Pharm Pharm Sci. 2015;7(3):28-39.

23. Shukla SD, Jain S, Sharma K, Bhatnagar M. Stress induced neuron degeneration and protective effects of Semecarpus anacardium Linn. And Withania somnifera Dunn. in hippocampus of albino rats: an ultrastructural study. Experimental Biology. 2000;38(10):1007-13.

24. Marquis JK. Pharmacological significance of acetylcholinesterase inhibition by tetrahydroaminoacridine. Biochem Pharmacol. 1990;40(5):1071-6. http://dx.doi. org/10.1016/0006-2952(90)90495-7.

25. Wilkinson DG. The pharmacology of donepezi. a new treatment for Alzheimer's disease. Expert Opin Pharmacother. 1999;1(1):121-35. http://dx.doi.org/10.1517/ 14656566.1.1.121; PMid:11249555.

26. Ellman GL, Courtney KD, Andres VJr, Featherstone RM. A new and rapid colorimetric determination of acetylcholinesterase activity. Biochem. Pharmacol. 1961;7(2):88-95. http://dx.doi.org/10.1016/0006-2952(61)90145-9.

27. Copeland RA. Evaluation of Enzyme Inhibitors in Drug Discovery A Guide for Medicinal Chemists and Pharmacologists. John Wiley \& Sons, Inc. 2005.

28. Riddles PW, et al. Ellman's reagent: 5, 5'-dithiobis (2-nitrobenzoic acid) - a reexamination. Anal Biochem. 1979;94(1):75-81. http://dx.doi.org/10.1016/00032697(79)90792-9.

29. Eyer P, Wore k F, Kiderlen D, Sinko G, Stuglin A, Simeon-Rudolf V, Reiner E. Molar absorption coefficients for the reduced Ellman reagent: reassessment. Anal Biochem. 2003;312(2):224-7. http://dx.doi.org/10.1016/S0003-2697(02)00506-7.

30. Spence JT, Cotton JW, Underwood BJ, Duncan CP. Elementary Statistics, $3^{\text {rd }}$ ed. Prentice-Hall, Englewood-Cliffs, NJ. 1976.

31. Nelson DL, Cox MM. Lehninger Principles of Biochemistry Fifth Edition. W. H. Freeman and Company. 2008;199.

32. Ma X, Tan C, Zhu D, Gang DR, Xiao P. Huperzine A from Huperzia species-an 
ethnopharmacolgical review. Journal of Ethnopharmacology. 2007;113(1):15-34. http://dx.doi.org/10.1016/j.jep.2007.05.030; PMid:17644292.

33. Kumar S, Seal JC, Okello EJ. Kinetics of acetylcholinesterase inhibition by an aqueous extract of Withania somnifera roots. Int. J. Pharm. Sci. Res, 2011;2:1188-92.

34. Yadav RS, Chandravanshi LP, Shukla RK, Sankhwar ML, Ansari RW et al., Neuroprotective efficacy of curcumin in arsenic induced cholinergic dysfunctions in rats. Neurotoxicology. 2011;32(6):760-8.

35. Kim DH, Jeon SJ, Jung JW, Lee S, Yoon BH, et al., Tanshinone congeners improve memory impairments induced by scopolamine on passive avoidance tasks in mice. Eur J Pharmacol. 2007-574(2-3):140-7.
36. Khan MT, Orhan I, Senol FS, Kartal M, Sener B, et al., Cholinesterase inhibitory activities of some flavonoid derivatives and chosen xanthone and their molecular docking studies. Chem Biol Interact. 2009-181(3):383-9.

37. Orhan I. Nature: A Substantial Source of Auspicious Substances with Acetylcholinesterase Inhibitory Action. Curr Neuropharmacol. 2013;11(4):379-87. http://dx. doi.org/10.2174/1570159X11311040003; PMid:24381529 PMCid:PMC3744902.

38. Orhan I, Sener B, Choudhary MI, Khalid A. Acetylcholinesterase and butyrylcholinesterase inhibitory activity of some Turkish medicinal plants. J Ethnopharmacol. 2004;91(1):57-60. http://dx.doi.org/10.1016/j.jep.2003.11.016; PMid:15036468.

Cite this article : Sobhani R, Pal AK, Bhattacharjee A, Mitra S, Aguan K. Screening Indigenous Medicinal Plants of Northeast India for their Anti-Alzheimer's Properties. Pharmacog J,2017;9(1):46-54. 